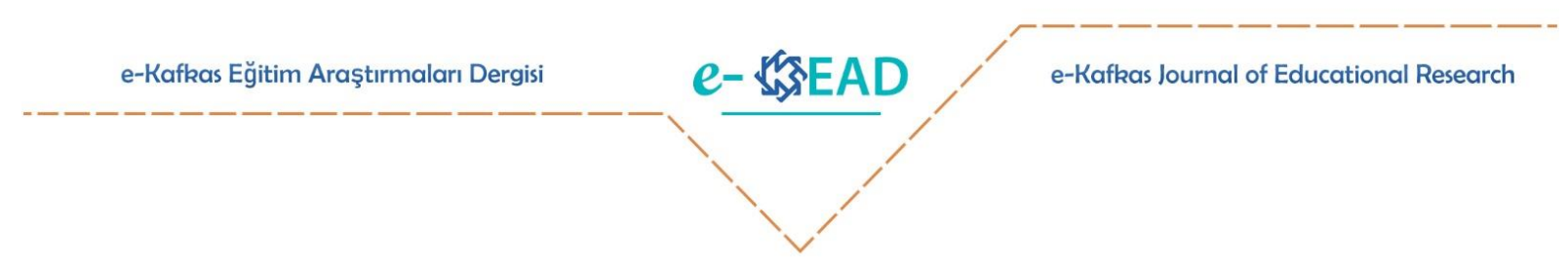

\title{
Öğretmen Adaylarının Vücudun pH Dengesi Konusundaki Bilgi Entegrasyon Düzeylerinin İncelenmesi
}

\author{
Fatma Şahin (1) $\triangle$ Filiz Kabapınar
}

Atıf: Şahin, F. ve Kabapınar, F. (2020). Öğretmen adaylarının vücudun pH dengesi konusunda bilgi entegrasyon düzeylerinin incelenmesi. e- Kafkas Eğitim Araştırmaları Dergisi, 7, 1-15. doi:10.30900/kafkasegt.664823

Kabul Tarihi:25.02.2020

\section{Öz}

Günümüzde problemler her geçen gün kompleks hale gelmektedir. Kompleks problemler de tek bir disiplinle çözülememekte, dolayısıyla disiplinlerarası bilgi entegrasyonunu zorunlu hale getirmektedir. Disiplinlerarası programların hazırlanması ve bu programı uygulanmasında öğretmenlerin rolü çok büyüktür. Öğretmenler kendileri disiplinerarası düşünme becerilerine sahipse öğrencileri de ilişki kurmada başarılı olmaktadır. $\mathrm{Bu}$ bağlamda bu çalışmada kimya öğretmen adaylarının $\mathrm{pH}$ konusundaki bilgi entegrasyon düzeylerinin incelemesi amaçlanmıştır. Çalışmanın problemini "Kimya öğretmen adaylarının kimya dersinde öğrendikleri pH kavram bilgisini farklı disiplinlere ait problemleri çözmede kullanabilmekte midirler?" sorusu oluşturmaktadır. Çalışmanın deseni, kimya öğretmen adaylarının vücudun $\mathrm{pH}$ dengesini disiplinlerarası açıklama düzeylerini belirlemek amacıyla durum çalışması olarak tasarlanmıştır. Araștırmanın çalışma grubunu, 2018-2019 eğitim öğretim yılında İstanbul ilinde bulunan bir devlet üniversitesinin kimya öğretmenliği dördüncü sınıfına devam eden 14 öğretmen adayı oluşturmaktadır. Çalışmada veri toplama aracı olarak 'pH Kavram Testi' kullanılmıştır. pH Kavram Testi, 19 açık uçlu sorudan oluşmaktadır. Soruların tasarlanmasında disiplinler arası geçişlere özel önem verilmiştir. Soruların bir bölümü tek disiplin ile cevaplamanın olanaklı olduğu sorulardır. Öte yandan bazı soruların cevaplanması için iki-üç disiplinlinin birlikteliğini gerekli kılarken bazıları ise çok disiplinin (üçten fazla) kullanımını gerektirmektedir. Araştırmadan elde edilen veriler içerik analizi ile analiz edilip yorumlanmıştır. Araştırma sonucunda, öğretmen adaylarının vücut $\mathrm{pH}$ 'sini açıklamada $\% 25$ 'i çoklu disiplinle, $\% 55$ 'inin iki-üç disiplinle, \%95'inin tek disiplinle açıkladıkları tespit edilmiştir.

Anahtar Sözcükler: pH, disiplinlerarası yaklaşım, bilgi entegrasyonu

\begin{abstract}
Today, problems are becoming more and more complex. Complex problems cannot be solved with a single discipline, thus making interdisciplinary information integration mandatory. The role of teachers in the preparation and implementation of interdisciplinary programs is very important. If teachers themselves have interdisciplinary thinking skills, their students are also successful in establishing relationships. In this context, in this study, it was aimed to investigate the knowledge integration levels of the chemistry teacher candidates on $\mathrm{pH}$. The problem of this study; Can the preservice chemistry teachers use the $\mathrm{pH}$ concept knowledge that they learned in chemistry class to solve multi-disciplinary problems? The study was designed as a case study to determine the chemistry teacher candidates' interdisciplinary explanation levels of the body's $\mathrm{pH}$ balance. The study group of the study consists of 14 candidate teachers attending the 4th year of chemistry teaching at a state university in Istanbul in the 2018-2019 academic year. In the study, a pH Concept Test was used as the data collection tool. pH Concept Test; consists of 19 open-ended questions. Special attention was paid to cross-disciplinary transitions in designing questions. Some of the questions are questions that can be answered with a single discipline. On the other hand, while some questions require the coexistence of two-three disciplines, others require the use of multi-discipline (more than three). The data obtained from the research were analyzed and interpreted by content analysis. In the study, qualitative content analysis was conducted. As a result of the study, the $\mathrm{pH}$ balance of the body was explained by $25 \%$ of the candidate teachers with multidisciplinary; $55 \%$ of them with two-three disciplines and $95 \%$ of them with one discipline
\end{abstract}

Keywords: $\mathrm{pH}$, interdisciplinary approach, knowledge integration 


\section{Giriş}

Son yıllarda araştırmacıların sıklıkla vurguladıkları nokta yerel ve küresel problemlerin tek bir disiplin yardımıyla çözülemeyeceğidir. Bu çerçevede disiplinlerarası bilgi entegrasyonunun gerek problemin tanımlanmasında gerekse çözüm sürecindeki önemi sıklıkla ifade edilmektedir. Özellikle bazı sorunların (enerji, çevre, sağlık, ekoloji gibi) doğası gereği hayati önem taşıdığı ve ayrı ayrı disiplin anlayışı ile çözülemeyeceği belirtilmiştir (Newell, 2007). Rhoten ve Parker (2004) üniversite ögrencilerini yirmi birinci yüzyıla hazırlanmak için eğitimleri sırasında disiplinlerarası düşünme pratiği yapmaları gerektiğini açıklamışlardır. Ancak fen eğitiminin temel uygulamaları hala disiplin temellidir. İlkokul ve ortaokulda öğrencileri fen bilimleri adı altında bütünleşik gibi görünen dersler almaktadır. Ancak sözü edilen ders içeriği incelendiğinde ünite ve öğrenme alanlarının yine disiplin temelinde ayrışmış olduğu görülmektedir. Lise seviyesinde ise dersler disiplin özelinde birbirinden tamamen ayrışmakta ve disiplinin uzmanı olan öğretmenler tarafından işlenmektedir. Bu durum öğrenme süreci ve beceri ediniminde disiplinler arası geçiş gerekliliğine ilişkin farkındalıklarını kısıtlarken öğrenci ve öğretmenlerin disiplinlerarası anlayışa sahip olma olasılıklarını da azaltmaktadır. Öğrenciler bireysel disiplinlerden çeşitli dersler alırken; bilgilerini disiplinler arasında nasıl bütünleştirecekleri konusunda rehbersiz kalmaktadır. Bu nedenle disipliner anlayıştan disiplinlerarası anlayışa geçilmesi gerektiği ve buna uygun eğitim programların hazırlanması gerektiği vurgulanmaktadır (Shen ve Linn, 2011). Disiplinlerarası transfer, öğrencilerin olayları anlamak veya problemleri çözmek için tek bir disiplin bağlamından öğrenilen açıklayıcı modelleri, kavramları, yöntemleri ve becerileri başarılı bir şekilde başka bir disipline uyguladıkları süreçleri ifade etmektedir. Bu olgu ilgili literatürde derinlemesine transfer olarak tanımlanmaktadır (Mansilla ve Duraising, 2005).

Disipliner yaklaşım ile öğrenim gören öğrenciler sürecin doğal bir sonucu olarak parçalanmış ayrı ayrı bilgi parçacıklarına ve fikirlere sahip olmaktadır. Fen öğretimi, öğrencilerin tutarlı açıklamalar oluşturmaları ve karmaşık problemleri çözebilmeleri için farklı alanlardan edindikleri bilgileri bütünleştirmelerine yardımcı olmak durumundadır (Shen ve Linn, 2011). Bilim insanları bunun için bilgi entegrasyonunu önermektedir (NGSS, 2013). Temel bilimsel ve mühendislik uygulamalarını (örneğin modelleme) ve disiplin sınırlarını aşan çapraz kavramları (örneğin enerji) vurgulayarak bu felsefeyi desteklemektedir. Disiplinlerarası anlayış merkezi bir kavram, tema ya da problemi incelemek için birden fazla disipline ait bilginin birbirleriyle ilişkilendirilmesi ve bilgi parçalarının bütünleştirilmesi gerekmektedir. Bu durum ise bir alanda çalışanların diğer alanla da ilgili bilgi sahibi olmasını ve ilgili alan çalı̧̧anları ile işbirliği yapmasını zorunlu kılmaktadır (DeWulf, François, PahlWostl ve Tailieu, 2007). Disiplinlerarası öğretim, bir problemin yaşamla ilişkilendirilerek kavramsallaştırması ve çözülmesidir. Disiplinlerarası problem çözme, bilim alanında bilgi ve düşüncenin birbirine bağlamasıdır. Araştırmacılar kompleks yaşam problemlerini çözmek için çeşitli disiplinlerin entegrasyonunu içeren stratejiler gerektiğini ve bu stratejilerinse sorgulama süreçlerini ve düşünme becerilerini içerdiğine dikkat çekmektedir (Davenport ve Jaeger, 1995; Davison, Miller ve Metheny, 1995).

Disiplinlerarası işbirliğinde, araştırmacılar arasında ortak bir anlayışa duyulan ihtiyacı ifade etmek için "Bilgi Entegrasyonu" kavramını kullanılmaktadır (Newell, 2007; Akera, 2007; Dewulf ve diğ. 2007). Newell (2007) bilgi entegrasyonunu "yenilikçi yeni dünya görüşleri yaratmak için iki veya daha fazla disiplinden kavramların harmanlanması" olarak tanımlamaktadır. Pennington (2008) bilgi entegrasyonunu farklı perspektiflerin kavramsal bütünleşmesi olarak ifade etmiştir. Araştırmacılar öğretim materyallerinin öğrencilerin disiplinlerarası bilgi entegrasyonunu geliştirmesine yardımcı olacak şekilde tasarlanması gerektiğini ifade etmektedir. Tek bir disiplin bilgisi konu ya da probleme kısıtlı bakış açısı sunmaktadır. Öğrenciler bir olaya ya da probleme bakarken; bir disiplin bilgisini farklı disiplin perspektifinden bakarak tanımalı, koordine etmeli ve arasında ilişkiler kurabilmelidir. Örneğin, öğrenciler bitkilerde kompleks bir kavram olan fotosentez olayını kavrarken; fizik perspektifinden ışık enerjisinin (1şı spektrumunun dalga boylarının belirli bir kısmının) kimyasal enerjiye nasıl dönüştürüldüğüne, kimya perspektifinden süreçteki kimyasal reaksiyonlara ve biyoloji perspektifinden; fotosentezin gerçekleştiği bir yap1 içindeki parçaların yap1 ve işlevlerini anlamaya çalışmak durumundadır. Ancak bu şekilde entegre bir fotosentez anlayışı geliştirilebilir. Disiplinlerarası bilgi entegrasyonunda üç özel süreç olduğu ifade edilmektedir. Bunlar; translasyon, transfer ve transformasyon'dur (Sung, Shen, Stanger-Hall, Wiegert, Brow ve Robertson, 2015). 
Translasyon: Bilgi entegrasyonunda, öncelikle farlı disiplinlerarasında dil birlikteliğin sağlanması gereklidir. Her ne kadar bilim disiplinleri temel ortak terminolojiyi paylaşsa da; her disipline özgü terminolojiler ve jargonlar vardır. Bazı durumlarda farklı disiplinler aynı kelimelere farklı anlamlar ya da yorumlar getirmektedir. Bu durumda önce farklı disiplinlerde iletişim kurmak için bilimsel terimlerin translasyonu yani ortak terminoloji geliştirilmesi gerekmektedir (Sung, Shen ve Zhang, 2012; Mansilla ve Duraising, 2007). Örneğin, osmotik basınç; bitki biyolojisinde, turgor basıncı osmoza bağlı olarak hücre içeriğinin, hücre duvarına karşı basınçtır. Hayvan ve tıbbi fizyolojide; kafa içi basınç, beyin hücrelerinde biriken yüksek sıvı tutma nedeniyle kafatasına uygulanan basınçtır. Bu iki disipline ait terim, iki somut osmotik basınç örneği olarak aslında benzerdir (Sung ve diğ, 2015). Osmoz kavramını öğrenen bir öğrenci bu terimler arasında bağlantı yapıp translasyon yapabilmelidir. Yani osmozun farklı alanlardaki farklı ifadelerini ve örneklerinin farkında olmalıdır. Örneğin, bitki biyolojisinde turgor basıncı, hücre çeperine hücre içeriğinin basıncıdır.

Transfer: Öğrencilerin bir disiplinde öğrendikleri bilgilerini başka bir disiplindeki bir problemi çözmede kullanmasıdır. Başka bir tanımla disiplinlerarası transfer, öğrencilerin olayları anlamak veya problemleri çözmek için tek bir disiplin bağlamından öğrenilen kavramları, yöntemleri ve becerileri başarılı bir şekilde başka bir disipline uyguladıkları süreçleri ifade etmektedir. $\mathrm{Bu}$ tanım literatürde derinlemesine transfer olarak tanımlanmaktadır (Chin ve Brown, 2000). Başarılı transfer, öğrencilerin daha önce edindikleri bilgileri, karşılaştıkları yeni problem durumunda etkinleştirerek, derinlemesine disiplinlerarası muhakemelerini ve iletişim becerilerini teşvik etmektedir. Bilginin transferinde ön bilgiler, öğrenme bağlamı, transfer kapsamı, problemin sunumu ve derinlemesine öğrenmeleri gibi birçok faktör katkıda bulunabilir ya da engelleyebilir (Bransford ve Schwartz, 1999; Chin ve Brown, 2000; Engle, 2006; Haskell, 2001; Klahr ve Carver, 1988; Larsen-Freeman, 2013). Yeterli disiplin bilgisi olan öğrenciler daha hızlı bir şekilde farklı disiplin bilgisini öğrenebilir ve uygulayabilirler (Hammer, Elby, Scherr ve Redish, 2005; NRC, 2012, Penington, 2014).

Transformasyon: Öğrencilerin bütünleşik bir anlayış geliştirerek, disiplinlerarası dönüşüm gerçekleştirme potansiyeline sahip olmasıdır. Bir disiplinden öğrenilen kavramların; farklı bir disiplinde fiziksel veya kavramsal olarak dönüştürülerek uygulanmasıdır. Örneğin, biyolojik bir kavram olan osmoz bilgisini ters osmoz (transformasyon) şeklinde gıda, çevre mühendisliğinde kullanılmasıdır. Dönüşüm süreci, osmozun ters osmoz olarak dönüştürüldüğü gibi ilgili bir disiplin bilgisini entegre etmeyi ve uygun başka bir disipline transfer etmeyi de gerektirmektedir (Shen ve Sung, 2014).

Gerçek yaşam problemlerini ve özellikle de sonuçları geniş kitleleri etkileyecek olan küresel sorunları çözmek için her kesimden öğrencilerin bir olay ya da problemle ilgili disiplinlerin perspektiflerini tanımlaması, koordine edebilmesi ve aralarında geçiş yapabilmesi gerekmektedir. Yeni çalışmalar öğrencilerin bilimi disiplinlerarası bir yaklaşımla öğrenmelerine yardımcı olacak programlar geliştirmeye başlamıştır (Slotta ve Linn, 2009). Bununla birlikte, bilişsel bir disiplinlerarası anlayış modeli oluşturmak için henüz yeterli sayıda çalışma bulunmamaktadır (Mansilla ve Duraising, 2007).

Eğitim programlarının geliştirilebilmesi için öğrencilerin disiplinlerarası geçişleri yapabildikleri ve yapamadıkları alanların belirlenmesi önemlidir. Eğitim programının içeriği ve etkinlikleri teorik temellerle değil uygulamadan kesitlerle desteklenebilir ve başarılı olma olasılığ 1 da arttırılabilir. Bilgi entegrasyonunun eğitimde uygulama örnekleri çok az sayıdadır. Bu çalışmada bu uygulamalara ve literatüre destek sağlayacağı düşünülmektedir. Buradan hareket ile bu araştırmada kimya öğretmen adaylarının $\mathrm{pH}$ ile ilintili bilgilerini farklı disiplinlere ait problemleri çözmede kullanabilme düzeylerini tespit etmek amaçlanmıştır.

Araştırmanın problemini, "Kimya öğretmen adaylarının kimyada öğrendikleri pH bilgisini farklı disiplinlere ait problemleri (vücudun $\mathrm{pH}$ dengesi) çözmede entegre etme düzeyleri nasıldır?" sorusu oluşturmaktadır.

\section{Yöntem}

$\mathrm{Bu}$ çalışma nitel araştırma desenlerinden durum çalışması olarak planlanmıştır. Mevcut literatürde durum çalışması farklı isimlerle anılmaktadır. Olay incelemesi, durum çalışması, örnek olay çalışması, örnek olay inceleme yöntemi ve vaka çalışması bu isimlerden bazılarıdır (Yıldırım ve Şimşek, 2008). Durum çalışması sosyal ve bilimsel araştırma yapmanın çeşitli yollarından biridir. Yin (2003)'e göre dört tür durum çalışması deseninden söz edilebilir: bütüncül tek durum deseni, iç içe geçmiş tek 
durum deseni, bütüncül çoklu durum deseni ve iç içe geçmiş çoklu durum desenidir. Bu çalışmada kimya öğretmen adaylarının vücudun $\mathrm{pH}$ dengesini disiplinlerarası açılama düzeylerini belirlemek hedeflenmiştir. Bu çerçevede çalışmaya konu olan tek bir durum söz konusudur ve "Bütüncül Tek Durum Deseni” varsayımları ve uygulama ilkeleriyle bu araştırmaya yön vermiştir. İsminden de anlaşılabileceği gibi bu desende tek bir analiz birimi (kimya öğretmen adayları) bütüncül ve tek bir ünite olarak ele alınacaktır.

\section{Çalışma Grubu}

Bu araştırmanın çalışma grubunu, 2018-2019 eğitim öğretim yılında İstanbul ilinde bulunan bir devlet üniversitesinin kimya öğretmenliği dördüncü sınıfına devam eden 14 öğretmen adayı oluşturmuştur. Katılımcıların ikisi erkek, 12'si ise kadın öğretmen adaylarından oluşmaktadır.

\section{Veri Toplama Araçları}

Durum çalışmasında sıklıkla yaygın olarak kullanılan veri toplama aracı açık uçlu sorulardan oluşan testlerdir (Q'Brien, 2003). Bu çalışmada açık uçlu sorulardan oluşan ' $\mathrm{pH}$ Kavram Testi' hazırlanmıştır. Test 19 kısa cevaplı açık uçlu sorudan oluşmaktadır. Sorular üniversite düzeyindeki öğrencilere göre hazırlanmıştır. Açık uçlu soruların $\alpha$ güvenirlik katsayısı .82'dir. Soruların tasarlanmasında disiplinler arası geçişlere özel önem verilmiştir. Soruların bir bölümü tek disiplin ile cevaplamanın olanaklı olduğu sorulardır. Öte yandan bazı soruların cevaplanması için iki-üç disiplinlinin birlikteliğini gerekli kılarken bazıları ise çok disiplinin (üçten fazla) kullanımını gerektirmektedir. Soruların tek disiplinli, iki-üç disiplinli ve çok disiplinli olduğuna karar vermede fizik, kimya ve biyoloji alanındaki öğretim üyelerinin görüşlerine başvurulmuştur. İki puanlayıcı arasındaki korelasyon katsayısı 0.84 olarak hesaplanmıştır. Tablo 1'de kavram testinde yer alan soruların kavram içeriği, ilişkili olduğu disiplinler ve disiplinlerarası düzeyleri görülmektedir.

Tablo 1.

Disiplinlerarası Düzeye Göre Hazırlanmış Vücut pH'si İle İlgili Açı Uçlu Sorulara Örnekler

\begin{tabular}{|c|c|c|c|}
\hline $\begin{array}{l}\text { Disiplinlerarası } \\
\text { ilişki } \\
\text { Kurma düzeyi }\end{array}$ & İlişkili disiplinler & İlgili içerik & Örnek soru \\
\hline $\begin{array}{l}\text { 1.Düzey } \\
\text { (tek disiplin) } \\
\text { Temel bilgiler }\end{array}$ & Biyoloji ya da Kimya & $\begin{array}{l}\mathrm{pH}, \text { Vücudun Tampon } \\
\text { Sistemleri }\end{array}$ & $\begin{array}{l}\text { Asit ve bazın tanımını yapınız. } \\
\text { En az iki farklı tanım } \\
\text { yapmalısınız. }\end{array}$ \\
\hline $\begin{array}{l}\text { 2.Düzey } \\
\text { (iki-üç disiplin) } \\
\text { Bilimsel } \\
\text { entegrasyon }\end{array}$ & $\begin{array}{l}\text { Biyoloji-Kimya-Sağlık } \\
\text { Biyoloji-Kimya- } \\
\text { Matematik } \\
\text { Biyoloj-Kimya- } \\
\text { Beslenme } \\
\text { Biyoloji - Kimya- Spor } \\
\text { Biyoloji-Kimya- } \\
\text { Teknoloji } \\
\end{array}$ & $\begin{array}{l}\text { Kanın pH'sinin merkezi } \\
\text { sinir sistemi ile } \\
\text { düzenlenmesi, Metabolik } \\
\text { Asidozis, alkalozis, } \\
\text { Egzersiz ve asidozis }\end{array}$ & $\begin{array}{l}\text { *Tampon nedir? Tampon sistem } \\
\text { nedir? } \\
\text { *Metabolik asidozis ve } \\
\text { alkolozis nedir? Etkileri } \\
\text { nelerdir? } \\
\text { *pH dengesi bozulan bir vücutta } \\
\text { hangi organ ve sistemler } \\
\text { etkilenir? Nasıl etkilenirler? }\end{array}$ \\
\hline $\begin{array}{l}\text { 3.Düzey } \\
\text { (çoklu disiplin) } \\
\text { Problem çözme }\end{array}$ & $\begin{array}{l}\text { Beslenme-Toplum } \\
\text { Sağlığı ve Spor-Tarım- } \\
\text { Mühendislik-Çevre- } \\
\text { İklim }\end{array}$ & $\begin{array}{l}\text { Tarım, toprak, iklim, } \\
\text { kayaçların bitkilerin } \\
\text { pH'sına etkisi, Asidozis ve } \\
\text { alkalozis'in diş sağlığına } \\
\text { ve tüm vücuda etkileri ve } \\
\text { bunların tedavisinin } \\
\text { ekonomik değeri, Bu } \\
\text { hastalıklardan korunmak } \\
\text { için geliştirilen } \\
\text { teknolojilerin ekonomiye } \\
\text { ve yaşam kalitesine etkisi }\end{array}$ & $\begin{array}{l}\text { *Ağız içi asitliğini azaltmak ve } \\
\text { dişleri en iyi temizleyen diş } \\
\text { macunun özelliği nasıl olmalı? } \\
\text { *Diş macununun miktarını } \\
\text { arttırırsak bazik özelliğini } \\
\text { arttırmış olur muyuz? } \\
\text { *Asidik içeceklerin sıklıkla } \\
\text { tüketilmesi vücuttaki hangi } \\
\text { organ / sistemleri etkileyebilir? } \\
\text { Nasıl etkiler? }\end{array}$ \\
\hline
\end{tabular}

\section{Araştırmanın Uygulaması}

Vücut pH'sine ilişkin Kimya Öğretmen adaylarına disiplinlerarası düşünme düzeylerini tespit edebilmek için araştırmacılar tarafından hazırlanan 19 sorudan oluşan $\mathrm{pH}$ kavram testi uygulanmıştır. Vücut pH'si ile ilgili disiplinlerarası soruların çözülebilmesi için öğretmen adaylarının çeşitli kaynaklardan faydalanması gerekmektedir. $\mathrm{Bu}$ nedenle öğretmen adayları soruları ders dışı 
zamanlarında zaman sınırlaması olmaksızın yanıtlamıştır. Katılımcılara soruları yanıtlarken istedikleri kaynaklardan faydalanabilecekleri ifade edilmiştir.

\section{Verilerin Analizi}

Katılımcıların pH kavram testindeki sorulara vermiş oldukları yanıtlar ilk olarak betimsel analiz yoluyla değerlendirilmiştir. Bu analizde öğretmen adaylarının sorulara vermiş oldukları yanıtlar doğru ya da yanlış olmaları temelinde değerlendirilmiştir. Bunu içerik analizi izlemiştir. İçerik analizi, Tablo 1 'de yer alan ilişki kurma (tek disiplinli, iki-üç disiplinli ve çok disiplinli) düzeylerine temelinde gerçekleştirilmiştir. Öğretmenlerin bilgi entegrasyonları translasyon (bilimsel bir kavramı farklı bilim dallarında tanımlarken ortak bir dil oluşturma), transfer (daha önce edinilen bilgilerin, karşılaşılan yeni problem durumunda etkinleştirip, derinlemesine, disiplinlerarası muhakeme etme) ve translasyon (bir disiplinden öğrenilen kavramları uygulayarak disiplinlerarası bir dönüşüm gerçekleştirme potansiyeli) düzeylerine göre analiz edilmiş̧tir. Her bir düzeyde öğretmen adaylarının iliş̧ki kurma düzeyleri; ilişkili disiplinler, ilgili içerik ve örnek açıklamalar olmak üzere farklı temalar çerçevesinde içerik analizine tabi tutulmuş̧tur.

\section{Araştırmanın Geçerlik ve Güvenirliği}

Nitel araştırma ölçülmesi gereken olguyu olabildiğince yansız ölçtüğü kadar bilimsel kabul görür. Araştırmanın bilimsel olarak kabul görmesi için geçerlik ve güvenirliğinin yüksek olması gerekmektedir. Lincoln ve Guba (1985) nitel araştırmanın niteliğini üst seviyeye taşıyabilecek bir takım stratejiler önermektedir. Araştırmada kullanılan iç geçerlik kavramı yerine inandırıcılık, dış geçerlik kavramı yerine aktarılabilirlik, iç güvenirlik yerine tutarlık, dış güvenirlik yerine teyit edilebilirlik kavramları kullanılmaktadır. Bu çalışmada araştırmanın inandırıcılığını arttırmak için araştırma konusu hakkında bilgili ve nitel araştırma yöntemleri konusunda uzman bir öğretim üyesi; araştırmanın tüm süreçlerini incelemiş; eleştirilerini ve yorumlarını araştırmacılara aktarmıştır. Çalışmada araştırmanın aktarılabilirliğini arttırmak ve dış geçerliliğini yükseltmek için verilerin nasıl toplandığı detaylı bir şekilde açıklanmaya çalışılmıştır. Araştırmadaki güvenirlik kavramı yerine Lincoln ve Guba (1985) nitel araştırmada tutarlılık kavramını önermektedir. Olay ve olguların aynen taklit edilmesi mümkün olmayacağ 1 için nitel araştırmada güvenirlikten ziyade tutarlılık ön plandadır. Bu çerçevede araştırmanın planlanması ve gerçekleştirilmesi süreci detaylarıyla ve gerekçeleriyle birlikte açıklanmaya çalışılmıştır. Nitel araştırmalarda dış güvenirliğin yerine geçen teyit edilebilirlik sağlanabilsin diye çalışmada araştırmacı çeşitlemesine başvurulmuştur. Araştırmadan elde edilen verilerin analizinde ikincil bir araştırmacı yer almıştır. Araştırmacılardan biri kimya diğeri biyoloji alanından öğretim üyesidir. İki araştırmacı arasındaki tutarlık teyit edilebilirlik kısacası dış güvenirlik olarak değerlendirilmiştir.

\section{Bulgular}

Yapılan bu çalışmada öğretmen adaylarının vücudun $\mathrm{pH}$ dengesi konusundaki bilgi entegrasyon düzeyleri nitel olarak analiz edilmiştir. Elde edilen bulgular aşağıda şekil ve tablolar halinde verilmiştir.

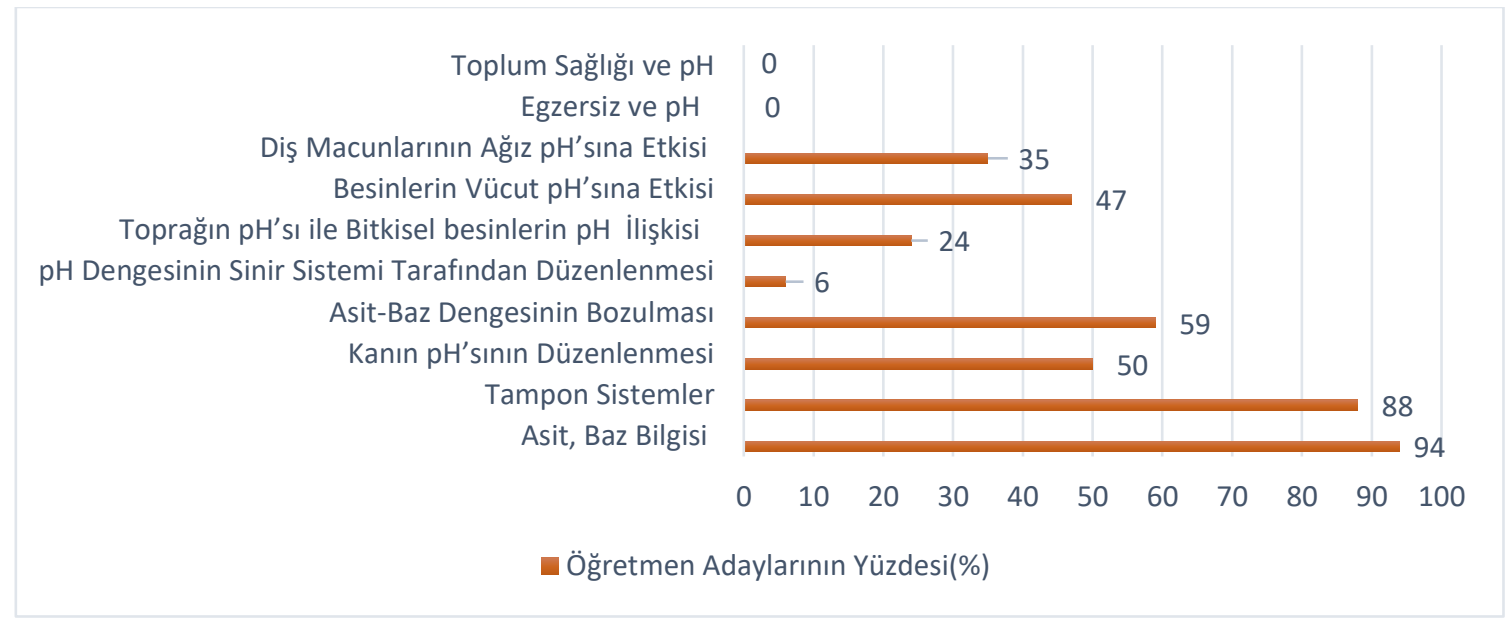

Şekil 1. Öğretmen Adaylarının Vücut pH'si ile İlgili Bilgi Düzeyleri 
Şekil 1'de öğretmen adaylarının vücut pH'sini disiplinlerarası açıklama düzeyleri görülmektedir. Buna göre öğretmen adayları alanlarının özelliği olarak asit baz (\%94), tampon sistemler (\%84), asit baz dengesinin bozulması (\%59) ve kanın pH düzeyi (\%50) kavramlarını açıklamada başarılı olmuşlardır. Ancak toplum sağlığı için pH'nin önemi, egzersiz ve $\mathrm{pH}$ ve vücudumuzda $\mathrm{pH}$ dengesinin sinir sistemi tarafından düzenlenmesi gibi farklı disiplinleri kullanarak açıklama üretmeleri gereken noktalarda başarısız olmuş görünmektedir.

Tablo 2'de öğretmen adaylarının yazılı yanıtlarının bilgi entegrasyonu açısından analizleri görülmektedir. Tabloda bilgi entegrasyon düzeylerine ilişkin ölçek kriterleri ve öğretmen adaylarının vücut $\mathrm{pH}$ 'si konusundaki yeterliliklerine yer verilmiştir.

Tablo 2.

Öğretmen Adaylarının Bilgi Entegrasyonu

\begin{tabular}{|c|c|c|c|}
\hline $\begin{array}{c}\text { Bilgi } \\
\text { entegrasyonu }\end{array}$ & Tanımlar & Örnekler & $\begin{array}{c}\text { Öğretmen adaylarında bilgi } \\
\text { entegrasyonu düzeyleri }\end{array}$ \\
\hline Translasyon & $\begin{array}{l}\text { Bilimsel bir kavramı farklı } \\
\text { bilim dallarında tanımlarken } \\
\text { ortak bir dil oluşturmadır. }\end{array}$ & $\begin{array}{l}\text { Kimyada görülen } \mathrm{pH} \\
\text { kavramını, biyoloji } \\
\text { tampon sistemler veya } \\
\text { egzersiz yaparken gibi } \\
\text { farklı biyolojik } \\
\text { sistemlerdeki pH'yı } \\
\text { tanımlarken aynı dili } \\
\text { kullanarak tanımlamak. }\end{array}$ & $\begin{array}{l}\text { Kimya öğretmen adayları } \\
\text { kendi alanlarında öğrendikleri } \\
\text { pH kavramını biyoloji, sağlık, } \\
\text { teknoloji alanları ile ortak bir } \\
\text { dilde birliktelik sağlamada } \\
\text { sinırlı kalmıştır. Sadece üç } \\
\text { öğretmen adayı bu dil birliğini } \\
\text { kurabilmiştir. }\end{array}$ \\
\hline Transfer & $\begin{array}{l}\text { Daha önce edinilen } \\
\text { bilgilerin, karşılaşılan yeni } \\
\text { problem durumunda } \\
\text { etkinleştirip, derinlemesine, } \\
\text { disiplinler arası muhakeme } \\
\text { ve iletişim becerilerini teşvik } \\
\text { etmedir. }\end{array}$ & $\begin{array}{l}\text { Kimyada öğrenilen pH } \\
\text { kavramı ile metabolik } \\
\text { asidoz ve alkaloz } \\
\text { durumlarındaki } \\
\text { problemi çözebilmek. }\end{array}$ & $\begin{array}{l}\text { Kimya öğretmen adayları daha } \\
\text { önce öğrendikleri pH bilgisini } \\
\text { farklı bilim dallarındaki } \\
\text { problemleri çözmede } \\
\text { zorlanmıştır. Sadece dört } \\
\text { öğretmen adayı bilgi transferi } \\
\text { yapabilmiştir. }\end{array}$ \\
\hline Transformasyon & $\begin{array}{l}\text { Bir disiplinden öğrenilen } \\
\text { kavramları uygulayarak } \\
\text { disiplinler arası bir dönüşüm } \\
\text { gerçekleştirme } \\
\text { potansiyelidir. }\end{array}$ & $\begin{array}{l}\text { Kimyada öğrenilen pH } \\
\text { ile ağız pH'sini } \\
\text { optimum da tutan diş } \\
\text { macunu geliştirme, kan } \\
\text { merkezlerinde kanın } \\
\text { uzun süreli saklanma } \\
\text { teknolojilerinin } \\
\text { geliştirilmesini } \\
\text { sağlamak. }\end{array}$ & $\begin{array}{l}\text { Kimya öğretmen adayları } \\
\text { kimyada öğrendikleri pH } \\
\text { bilgisini yeni bir teknolojik ya } \\
\text { da ürün oluşumu için } \\
\text { kullanamamıştır. }\end{array}$ \\
\hline
\end{tabular}

Tablo 2'ye göre, öğretmen adaylarının üçü translasyon, dördü ise transfer düzeyinde cevap vermiştir. Öğretmen adaylarının hiç biri kimyada öğrendikleri $\mathrm{pH}$ bilgisini yeni bir teknolojik ya da ürün oluşumu için kullanmayı gerektiren transformasyon düzeyine ulaşamamıştır. Öğretmen adaylarının içerik bilgisini disiplinler arası açıklama düzeyleri Şekil 2'de görülmektedir.

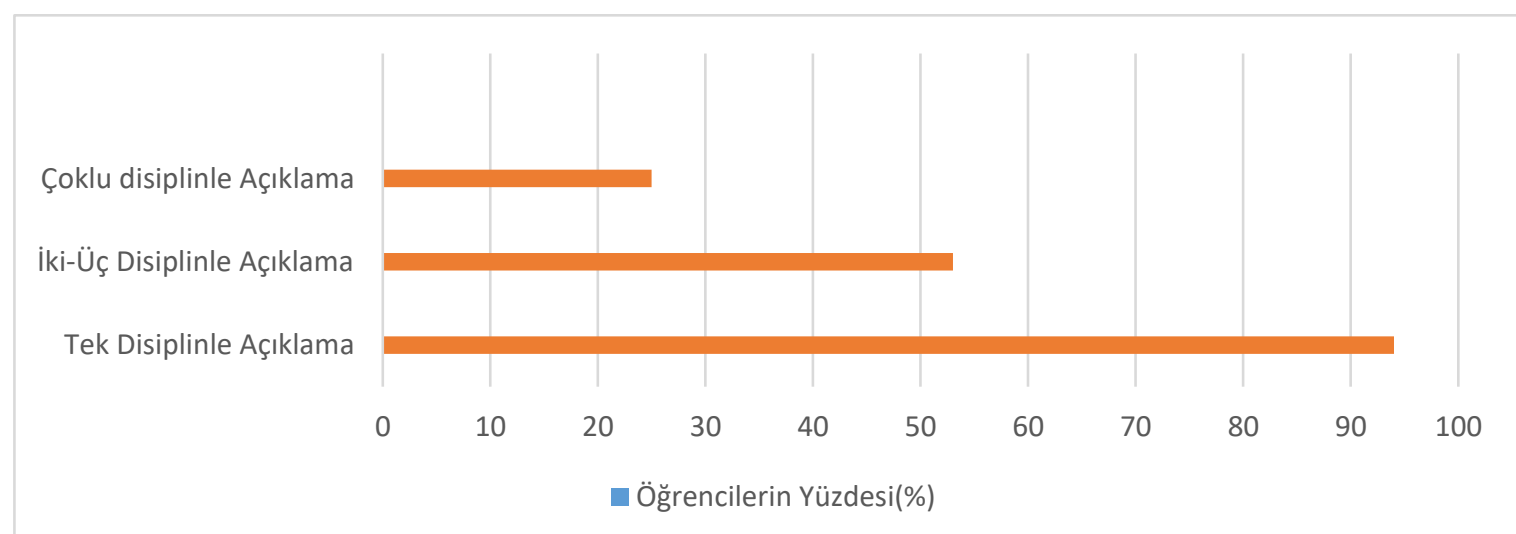

Şekil 2: Öğretmen Adaylarının Vücut pH'si ile İlgili İçerik Bilgisini Disiplinlerarası Açıklama Düzeyleri 
Şekil 2'den öğretmen adaylarının \%25'inin çoklu disiplin; \%55'inin 2-3 disiplinli; \%95'inin tekli disiplinli soruları açıklayabildikleri görülmektedir. Öğretmen adaylarının açık uçlu sorulara vermiş oldukları cevapların disiplinlerarası anlayışa göre içerik analizi Tablo 3, Tablo 4 ve Tablo 5'de verilmiştir.

Tablo 3.

Öğretmen Adaylarının Çok Disiplinli Açıklamaları

\begin{tabular}{|c|c|c|}
\hline İçerik & $\begin{array}{l}\text { Öğrenci açıklamaları } \\
\text { (kanıtlar) }\end{array}$ & $\begin{array}{c}\text { Öğrencilerin kurmada eksik kaldıkları ilişkilere } \\
\text { örnekler }\end{array}$ \\
\hline $\begin{array}{l}\text { Toprağın Bitkisel } \\
\text { Besinlerin Asit- } \\
\text { Bazlığına Etkisi }\end{array}$ & $\begin{array}{l}\text { Öğretmen adayları toprağın } \\
\text { pH'sinin ve sulamanın etkili } \\
\text { olabileceğini belirtmişlerdir. }\end{array}$ & $\begin{array}{l}\text { Öğretmen adayları toprağın yapısının yanında } \\
\text { tarımda kullanılan kireç, kükürt ve gübre } \\
\text { kullanımının etkisi, iklim ve çevre kirliliğine bağlı } \\
\text { asit yağmurlarının, kayaların jeolojik özellikleri, kök } \\
\text { solunumu, toprağın yaşı ve meyilli ve topoğrafya } \\
\text { etkisinden bahsetmemişlerdir. }\end{array}$ \\
\hline $\begin{array}{l}\text { Asit Baz Dengesi } \\
\text { ve Beslenme } \\
\text { İlişkisi }\end{array}$ & $\begin{array}{l}\text { Vücudun asit baz dengesinde } \\
\text { günümüzün popüler konusu olan } \\
\text { alkali beslenmeden bahsetmişlerdir. }\end{array}$ & $\begin{array}{l}\text { Vücudu asidik ve alkali besinlere örnekler } \\
\text { verememişlerdir. Ayrıca yenen besinlerin tükürük, } \\
\text { mide barsak pH'sini etkileyebileceği } \\
\text { açıklanmamıştır. }\end{array}$ \\
\hline
\end{tabular}

Tükürük ağız $\mathrm{pH}$ 'sini düzenleyen en önemli faktör florit mineralleşmeyi sağlamasına ek olarak plakta

Tükrük ağı PH'sini düzenleyen en Diş Macunlarının önemli faktörün Florid olduğu ve A $\breve{g} 1 \mathrm{z}$ pH'sına Etkisi
Islanan diş macunu etken maddesini kaybettiği tüm öğretmen adayları tarafından açıklanmıştır. bulunan yemek artıklarından faydalanan bakterilerin gelişmesini yavaşlatarak asit oluşumunu düşürdüğü açıklanamamıştır. Yine toplum sağlığı ve ekonomiyi etkileyen diş çürüklerinin önlenmesinde tükürük pH'sinin önemi belirtilmemiştir. Ağıza alınan yiyeceklerden asit üretilmesi ve dolayısı ile çürük yapma özellikleri plak pH'ı ölçümü ile önceden tespit edilebilmektedir.

Spor ile pH arasındaki ilişki; yüksek yoğunluktaki fiziksel egzersiz ilk olarak metabolik asitoza neden

$\mathrm{pH}$ Dengesi ve

pH ile spor arasında ilişki Egzersiz kurulamamıştır. olmaktadır. Kan laktat düzeyinin artması ile $\mathrm{PH}$ düşmektedir. pH'ın düşmesi kasılma mekanizmasını olumsuz yönde etkilemektedir

Kan

Merkezlerinde

Kanin

saklanmasında pH'nin Önemi
Hiçbir öğretmen adayı bu ilişkiyi kuramamıştır
Banka kanında kanın pıhtılaşmasını engellemek için sitrat kullanılmaktadır. Böylece Metabolik alkaloz gelişir: Bir sitrat 3 bikarbonat üretimine neden olur. Aslında sitratlı banka kanı asidiktir, $\mathrm{pH}$ 7,1 ve her hafta 0.1 azalır (eritrosit yıkımı ile ortaya çıkan Laktat ve piruvat ile)

Vücut pH'sinin bozulması ile oluşan hastalıkların

pH Dengesi ile Toplum Sağlığı, Ekonomi ve Teknoloji İlişkisi
Öğretmen adayları sadece "önemlidir" diye belirtmişler açıklama yapamamışlardır. toplumu etkileyeceği ve bunun bir ekonomik karşılığı olduğu ilişkisi kurulamamıştır.

Yine $\mathrm{pH}$ dengesinin bozulmasını önceden tespit etmek (diş çürüklerini çürümeden önce tükürük pH ölçüm cihazlarının geliştirilmesi, ilaç ve tedavi aletlerinin oluşturulması ile teknoloji ilişkisi kurulamamıştır. 
Tablo 4

Öğretmen Adaylarının İki-üç Disiplinle Açıklamaları

\begin{tabular}{|c|c|c|}
\hline İçerik & $\begin{array}{c}\text { Öğrenci Açıklamaları } \\
\text { (Kanıtlar) }\end{array}$ & $\begin{array}{c}\text { Öğrencilerin Kurmada Eksik Kaldıkları İlişkilere } \\
\text { Örnekler }\end{array}$ \\
\hline $\begin{array}{l}\text { Asit baz dengesi } \\
\text { (tampon } \\
\text { sistemler) }\end{array}$ & $\begin{array}{l}\text { Öğretmen adayları tampon } \\
\text { sistemleri; } \\
\text { Kimyasal Tamponlar (Kanda); } \\
\text { Bikarbonat, Hemoglobin, } \\
\text { c. Protein, Fosfat sistemler } \\
\text { Solunum Sistemi } \\
\text { Boşaltım Sistemi } \\
\text { olarak sınıflamışlar ve tampon } \\
\text { sistemi tanımlamışlardır. }\end{array}$ & $\begin{array}{l}\text { Öğretmen adaylarının hiç biri tampon sistemlerde } \\
\text { karaciğer ve kemiklerden bahsetmemiştir. }\end{array}$ \\
\hline $\begin{array}{l}\text { Kanın ph’sının } \\
\text { Düzenlenmesi }\end{array}$ & $\begin{array}{l}\text { Öğretmen adaylarının büyük bir } \\
\text { kısmı vücudun asit baz dengesinde } \\
\text { tampon sistemleri } \\
\text { sinıflandırabilmiştir. Ancak bunları } \\
\text { bir problem (kanın pH'si asidik } \\
\text { olursa bu nasıl normale dönüşür? } \\
\text { Sorusunu sistematik olarak } \\
\text { açıklayamamışlardır. }\end{array}$ & 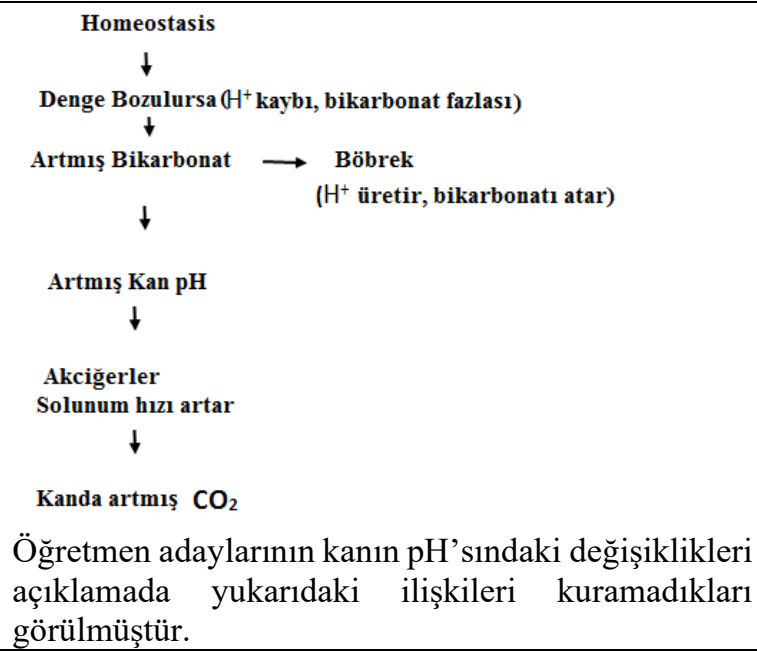 \\
\hline $\begin{array}{l}\text { Asit baz } \\
\text { dengesinin } \\
\text { bozulması } \\
\text { (hastalıklar) }\end{array}$ & $\begin{array}{l}\text { Öğretmen adayları vücutta } \mathrm{pH} \\
\text { dengesi bozulunca asidoz veya } \\
\text { alkaloz meydana geleceğini } \\
\text { belirtmişlerdir. }\end{array}$ & $\begin{array}{l}\text { Öğretmen adayları vücutta oluşan asidoz ve alkoloz } \\
\text { sonucu oluşan hastaklıklara örnekler verememiştir. } \\
\text { Metabolik asidozis sonucunda Kardiovaskuler, } \\
\text { Solunum ve merkezi sinir sistemi hastalıkları(diyabet, } \\
\text { KOAH, böbrek yetmezliği, beyin tümörleri, solunum } \\
\text { hastalıkları gibi). } \\
\text { Metabolik alkaloz varlığında, birçok enzim ve } \\
\text { proteinin fonksiyonları bozulabilmektedir. }\end{array}$ \\
\hline $\begin{array}{l}\text { Ph Dengesinin } \\
\text { Sinir Sistemi } \\
\text { Tarafindan } \\
\text { Kontrolü }\end{array}$ & $\begin{array}{l}\text { Öğretmen adayları pH dengesinde } \\
\text { merkezi sinir sitemi kontrol görevi } \\
\text { yapar diyerek açıklamıştır. İlişkileri } \\
\text { kuramamıştır. }\end{array}$ & $\begin{array}{l}\text { Öğretmen adaylarının vücudun } \mathrm{pH} \text { dengesinin nasıl } \\
\text { düzenlendiği ile ilgili ilişkileri kuramadıkları tespit } \\
\text { edilmiştir. İlişkileri gösteren kavram şeması aşağ1da } \\
\text { görülmektedir. }\end{array}$ \\
\hline
\end{tabular}


Tablo 5.

Öğretmen Adaylarının Tek Disiplinli Açıklamaları

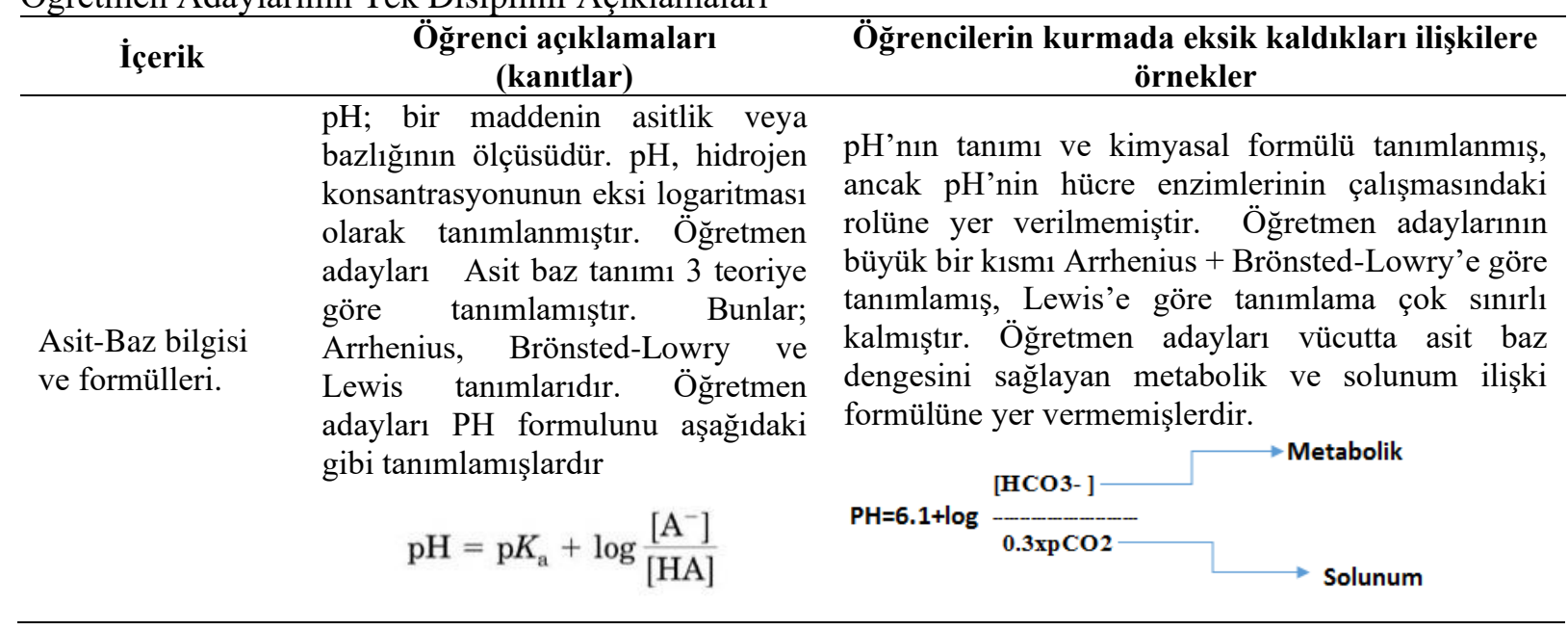

\section{Tartışma, Sonuç ve Öneriler}

Yapılan çalışmada kimya öğretmen adaylarının vücut kimyası ile ilgili bilgi entegrasyon düzeyleri tespit edilmeye çalışılmıştır. Öğretmen adayları alanlarının özelliği olarak asit- baz (\%94), tampon sistemler (\%84), asit baz dengesinin bozulması (\%59), kanın $\mathrm{pH}$ düzeyi (\%50) kavramlarını açıklamada başarılı olmuştur. Ancak toplum sağlığı için pH'nin önemi, egzersiz ve pH, vücudumuzda pH dengesinin sinir sistemi tarafindan düzenlenmesi gibi farklı disiplinleri kullanarak açıklama gerektiren kavramlarda başarısız oldukları belirlenmiştir. Cevaplar bilgi entegrasyonu açısından incelendiğinde; öğretmen adaylarının üçü translasyon, dördü transfer düzeyinde cevap verdiği görülürken; hiçbir öğretmen adayının kimyada öğrendikleri $\mathrm{pH}$ bilgisini yeni bir teknolojik ya da ürün oluşumu için kullanmayı gerektiren transformasyon düzeyine ulaşamadığı görülmüştür. Vücut pH'sini açıklamada öğretmen adaylarının \%25'i çoklu disiplin; \%55'inin iki-üç disiplini; \% \% $\% 5$ 'inin tek disiplini kullandıkları tespit edilmiştir.

Literatürde disiplinlerarası düşünme becerilerinin geliştirilmesi ve bunun değerlendirmesi için ortak terminolojileri kullanmanın da önemli olduğu belirtilmiştir. Bu çalışmalar birçok öğrencinin terminoloji sorunları nedeniyle disiplinlerarası iletişim kurmakta zorluk çektiklerini vurgulamıştır (Sung, 2013). Bu durum disiplinlerarası öğrenmeyi teşvik etmek için öğretmenlerin belirli önlemler almaları gerektiğini göstermektedir. Disiplinlerarası öğretim yaklaşımı çerçevesinde, öğretmenlerin çeşitli uzmanlık alanlarındaki öğretmenlerle işbirliği yaptıklarında, öğrencilerinin her alandaki başarılarının arttı̆ğ gösterilmiştir (Jones, Rasmussen ve Moffit, 1997; Mathiason ve Freeman, 1997). İşbirliği yoluyla; öğretmenlerin bilgi ve becerileri derinleşerek gelişirken, diğer yandan da genel iletişim ve işbirliği becerileri gelişmektedir (Lamanauskas, 2014). Yapılan bu çalışmada da öğretmen adayları pH kavramına sadece kendi disiplinlerindeki terminolojiyi çok iyi bildikleri halde biyolojik sistemlerdeki terminolojide bazı kavram kargaşası yaşadığı görülmüştür. Kendilerine açıklama yapıldığında aslında bunu bildiklerini söylemişlerdir. pH tanımını hem kimya hem de biyolojik içeriği kapsayacak şekilde tanımlayan sadece üç öğretmen adayı olmuştur.

Sağlık, gıda, enerji ve çevre ile ilgili kompleks problemlerin çözümü için bir çok disipline ait bilgi ve becerinin bir araya getirilmesi gerekmektedir. Bu da farklı disiplin öğretmenlerinin işbirliği yapmasını gerekli kılmaktadır (Sung, Shen ve Zhang, 2015; Sung, 2013). Disiplinlerarası ilişki kurmay1 kolaylaştırmak için farklı disiplin öğretmenlerinin işbirliği yapması ve farklı dersleri disiplinlerarası öğrenmenin ortak hedeflerinde buluşturacak programlar oluşturulması önerilmektedir. Okul yöneticilerinin farklı disiplinlerin öğretmenleri arasındaki işbirliğini teşvik etmek ve kolaylaştırmak için bu programa dâhil edilmeleri çözüm sürecini kolaylaştırıcı bir etmen olarak işlev görebilir. Öğretmenlerin işbirliğine istekliliği ve ilgileri ile okul yöneticisinin rolünün önemi, farklı alanlardaki uzmanların başarılı işbirliğini sağlamak için önemli faktörler olarak kabul edilmiştir (Lamanauskas, 2014). Yapılan bu çalışmada bir disiplinde yetişmiş bir öğretmen adayının disiplinlerarası bir anlayış isteyen bilgi entegrasyonunu yapması oldukça zor olmuştur. Bunun için öğretmen adaylarına meslek 
öncesi eğitimlerinde farklı disiplin alanlarıyla çalışma yapabilecekleri disiplinlerarası derslere yer verilmesi ve farklı bölümlerle işbirliği yapmaları desteklenmelidir.

Ma (1999), öğretmenlerin iyi entegre edilmiş bilgiye ihtiyaç duyduklarını iddia etmektedir. Bu entegrasyon öğretmenlerin bilgilerini esnek bir şekilde farklı disiplinlerde bilgilerini kullanmalarına ve yeni uygulamalara izin vereceğini belirtmiştir. Lederman, Gess-Newsome ve Latz, (1994) bazı öğretmenlerin hizmet öncesi eğitim programı boyunca öğrendikleri bilgilerinin entegrasyonunu sağlarken, bazılarının ise entegrasyonu sağlayamadığını bulmuşlardır (Lortie, 1975; Putnam ve Borko, 2000; Wilson ve Berne, 1999). Entegre bilginin önemi nedeniyle, öğretmen adayının bilgilerini entegre etmelerinin önemi de ortadadır (Smithey, 2003). Davis, (2003), Linn ve Eylon, (1996) bilgi entegrasyonun; öğrencilerin bilgilerinin sağlam ve kullanılabilir olarak geliştirmede önemli olduğunu bildirmişlerdir. Clark ve Linn, (2003) bilgi entegrasyonu perspektifinin öğrencilerin fen ve diğer konularda öğrendiklerini analiz etmek ve tanımlamak için kullanılabileceğini, bunun da yaşamsal problemlerin çözümüne ve teknolojik ürünlerin üretilmesine katkı sağlayacağını belirtmiştir. Literatürde yapılan bu çalışmalarda da belirtildiği gibi bilgi entegrasyonunu destekleyecek kompleks yaşam problemleri ile öğretmen adaylarını lisans eğitiminde tanıştırmak ve deneyim sahibi olmaları sağlanmalıdır.

Çalışmalar bilgi entegrasyonunun önemini ve eğitim programlarında gerçek yaşam süreçlerine yer verilerek geliştirilmesini önermektedir (Newell, 2007; Akera, 2007; Dewulf ve diğ. 2007). Ancak öğretmen ve ögrenciler karşılaştığı bazı zorluklar nedeniyle bilgi entegrasyonuna uzak durmaktadır. Bilimsel bilginin patlaması ile birlikte çok fazla bilginin olması disipliner eğitimi bile zorlaştırırken; disiplinlerarası entegrasyonu daha da zor hale getirmektedir. Disiplinlerarası bilgi entegrasyonu öğretmenlerinin diğer alan öğretmenleriyle işbirliği yapmaları önerilmektedir. Başka bir zorluk da disiplinler arasında terminoloji birliğinin sağlanamamasıdır. Bu zorluk da işbirliği ile çözülebileceği belirtilmiştir (Sung, 2013). Farklı disiplinlerden gelen içeriğin bütünleşik olarak anlaşılması, çağdaş toplumumuzun karmaşık problemleriyle başa çıkabilecek uzmanları yetiştirmek önemli bir husustur (Ford ve Forman, 2006; UNESCO, 2005). Bu nedenle, disiplinlerarası bir yaklaşım benimsenmeli ve öğretim programı bu anlayışa göre yapılandırılmalıdır. Disiplinlerarası program innovasyonu ve yaratıcılığı teşvik eder ve akademik bilgilerin çağdaş toplumun yeni talepleriyle daha iyi ilişkilendirmesini sağlar (Sawyer, 2006). Liu ve diğ. (2008) yaptıkları çalışmada öğrencilerin TíMMS ve PISA sınavları öğrencilerin bilgilerini entegre etmelerini beklemektedir. Ancak eğitimde bunun yapılmadığı belirtilmiştir. Yapılacak araştırmalarda buna yoğunlaşılması gerektiği bildirilmiştir (DiSessa, 2000; Edelson, 2001; Linn ve diğ, 2004; Quintana, Reiser, Davis, Krajcik, Fretz ve Golan 2004).

Yapılan çalışmada kimya öğretmen adaylarının vücudun $\mathrm{pH}$ dengesi konusundaki bilgi entegrasyon düzeyleri incelenmiştir. Öğretmen adayları vücudun $\mathrm{pH}$ 'sini tek disiplin bilgisiyle açıklamaya çalışmıştır. Açık uçlu soruları farklı disiplin bilgilerini kullanarak açıklayamamışlardır. $\mathrm{Bu}$ durumun nedenleri arasında öğretmen adaylarının farklı disiplinleri içeren kompleks problemlerle karşılaşmamış olmaları, kimya disiplininde öğrendikleri bir kavramı ilgili disiplin dışında da varlığını sürdürdügünün farkında olmamaları ve uzmanlıklarının dışındaki disiplinlerde bilgili olmak zorunda hissetmedikleri sayılabilir. Bu nedenlerin hangisinin öncül işlevi gördüğü ve disiplinlerarası geçişin önünde bariyer oluşturduğunun belirlenmesi önemli olacaktır. $\mathrm{Bu}$ çerçevede araştırmaların gerçekleştirilmesi gelecekte atılacak adımlar için basamak oluşturacaktır. Yine farklı öğrenim seviyesinden öğrencilerle yapılacak çalışmalar ilkokul, ortaokul ve lise öğrencilerinin disiplinlerarası entegrasyonun ne ölçüde gerçekleştirilebildiğini ortaya koyabilir. Günümüzdeki problemlerin tek disiplinle açıklanamayacağını, bu nedenle öğretmen adaylarının problemlere farklı disiplinler açısından bakabilme tecrübesi kazandırılması gerekmektedir. Bu çerçevede öğretmen yetiştiren kurumlarda hizmet öncesi öğretmen eğitimi programlarının geliştirilmesi, denenmesi ve sonuçlarının değerlendirilmesi önerilebilir. 


\section{Kaynakça}

Chin, C. ve Brown, D. E. (2000). Learning in science: A comparison of deep and surface approaches. Journal of Research in Science Teaching, 37(2), 109-138.

Clark, D. ve Linn, M. C. (2003). Designing for knowledge integration: The impact of instructional time. The Journal of the Learning Sciences, 12(4), 451-493.

Davenport, M. R. ve Jaeger, M. (1995). Integrating curriculum. The Reading Teacher, 49 (1), 60-62.

Davison, D. M., Miller, K. W. ve Metheny, D. L. (1995). What does integration of science and mathematics really mean? School Science and Mathematics, 95 (5), 226-230

Davis, E. A. (2003). Prompting middle school science students for productive reflection: Generic and directed prompts. The Journal of the Learning Sciences, 12(1), 91-142.

DeWulf, A., François,G., Pahl-Wostl, C. ve Tailieu. T. (2007). A framing approach to crossdisciplinary research collaboration: experiences from a large-scale research project on adaptive water management. Ecology and Society 12(2), 14.

DiSessa, A. A. (2000). Changing minds: Computers, learning and literacy. Cambridge, MA: MIT.

Press Edelson, D. C. (2001). Learning-for-use: A framework for the design of technology-supported inquiry activities. Journal of Research in Science Teaching, 38(3), 355-385.

Engle, R. A. (2006). Framing interactions to foster generative learning: A situative explanation of transfer in a community of learners classroom. Journal of the Learning Sciences, 15(4), 451498.

Hammer, D., Elby, A., Scherr, R. E. ve Redish, E. F. (2005). Resources, framing, and transfer. In J. Mestre (Ed.), Transfer of learning from a modern multidisciplinary perspective (pp. 89-120). Greenwich,CT: Information Age Publishing.Ulusal Araştırma Konseyi [NRC], 2000, 2012).

Haskell, R. A. (2001). Transfer of learning. San Diego, CA: Academic Press.

Jones, B, F., Rasmussen, C. M. ve Moffit, M. C. (1997). Real-life problem solving: A collaborative approach to interdisciplinary learning. Washington D. C: American Psychological Association.

Klahr, D. ve Carver, S. M. (1988). Cognitive objectives in a LOGO debugging curriculum: Instruction, learning, and transfer. Cognitive Psychology, 20(3), 362-404.

Lamanauskas, V. (2014). Science and math teachers'collaboration: How to develop it seaking pupils' success at school. Problems of Education in the 21st Century, 62, 5-7.

Larsen-Freeman, D. (2013). Transfer of learning transformed. Language Learning, 63, 107-129.

Lederman, N., Gess-Newsome, J. ve Latz, M. (1994). The nature and development of preservice science teachers' conceptions of subject matter and pedagogy. Journal of Research in Science Teaching, 31(2), 129-146.

Lincoln, Y.S. ve Guba, E.G. (1985). Naturalistic Inquiry. Newbury Park, CA: Sage Publications.

Linn, M. C. ve Eylon, B.S. (1996, July). Lifelong science learning: A longitudinal case study. Paper presented at the Cognitive Science Conference, San Diego, CA.

Linn, M. C., Davis, E. A., ve Bell, P. (Eds.). (2004). Internet environments for science education. Mahwah, NJ: Lawrence Erlbaum Associates.

Liu, O.L., Lee, H. S., Hofstetter, C. ve Linn, M.C.(2008). Assessing Knowledge Integration in Science: Construct, Measures, and Evidence. Educational Assessment, 13(1), 33-55

Lortie, D.C. (1975). School Teacher: A Sociological Study. Chicago: University of Chicago Press.

Ma, L. (1999). Knowing and teaching elementary mathematics. Mahwah, NJ: Lawrence Erlbaum.

Mansilla, V.B. ve Veronica B. (2005). Assessing Student Work at Disciplinary Crossroads. Change The Magazine of Higher Learning, 37 (1), 14-21.

Mansilla, V. B. ve Duraising, E. D. (2007). Targeted assessment of students' interdisciplinary work: An empirically grounded framework proposed. The Journal of Higher Education, 78(2), 215237.

Mathiason, S. ve Freeman, M. (1997). The logic of interdisciplinary studies. Paper presented at the Annual Meeting of the American Educational Research Association, Chicago, IL (March 2428, 1997). Retrieved 1/04/2019, from http://files.eric.ed.gov/ fulltext/ED418434.pdf

National Research Council. (2012). Discipline-based education research: Understanding and improving learning in undergraduate science and engineering. Board on Science Education, 
Division of Behavioral and Social Sciences and Education. Washington, DC: The National Academies Press.

National Research Council. (2014). Developing assessments for the next generation science standards. Committee on developing assessments of science proficiency in K-12. Board on testing and assessment and board on science education. Washington, DC: The National Academies Press.

Newell, W. H. (2007). Decision making in interdisciplinary studies. In G. Morçöl (Ed.), Handbook of decision making. New York: CRC. NGSS. (2013). Next generation science standards: For states, by states. Washington, DC:

The National Academies Press. (Jacobson ve ark., 2004; Slotta, J. D., \& Linn, M. C. (2009). WISE science:Web-based inquiry in the classroom. New York, NY: Teachers' College Press.

Pennington D. (2008). Cross-disciplinary collaboration and learning. Ecol. Soc. 13(2):8 URL: http://www.ecologyandsociety. org/vol13/iss2/art8/

Putnam, R. ve Borko, H. (2000). What do new views of knowledge and thinking have to say about research on teacher learning? Educational Researcher, 29(1), 4-15.

O'Brien, R. (2003). An Overview of the Methodological Approach of Action Research . http://www.wb.net/robrien/papers/ arfinal.html adresinden alınmıştır.

Quintana, C., Reiser, B. J., Davis, E. A., Krajcik, J., Fretz, E., Duncan, R. G., Kyza, E., Edelson D. ve Soloway, E. (2004). A scaffolding design framework for software to support science inquiry. Journal of the Learning Sciences, 13(3), 337-386

Rhoten, D. ve Parker, A. (2004). Risks and rewards of an interdisciplinary research path. Science, 306 ( 5704), 2046.

Shen, J. ve Linn, M. C. (2011). Connecting scientific explanations and everyday observations: A technology enhanced curriculum on modeling static electricity. International Journal of Science Education. 33(12), 1597-1623.

Shen, J., Lydia, O. ve Sung, S. (2014). Designing Interdisciplinary Assessments in Sciences for College Students: An example on osmosis. International Journal of Science Education. 36(11), $1773-1793$

Smithey, J. (2003). Two perspectives on expertise in elementary science teaching. Ann Arbor, MI: University of Michigan.

Sung, S., Shen, J. ve Zhang, D. (2012). Toward a cognitive framework of interdisciplinary understanding. In 10th International Conference of the Learning Sciences: The Future of Learning, ICLS 2012 - Proceedings, 1, 299-306

Sung, S. (2013). Understanding undergraduate interdisciplinary science education from cognitive, curricular, and assessment perspectives (Unpublished doctoral dissertation). University of Georgia, Athens, GA.

Sung, S., Shen, J., Stanger-Hall, K. F., Wiegert, C., Li, W., Brown, S. ve Robertson, T. (2015). Toward interdisciplinary perspectives: Using osmotic pressure as an example for analyzing textbook explanations. Journal of College Science Teaching, 44(4), 76-87.

Wilson, S. M. ve Berne, J. (1999). Teacher learning and the acquisition of Professional knowledge: An examination of research on contemporary Professional development. In A. Iran-Nejad (Ed.), Review of research in education. 173-209.Washington, DC: AERA.

Yıldırım, A.ve Şimsek, H. (2008). Sosyal bilimlerde nitel arastırma yontemleri. Ankara: Seckin Yayınları.

Yin, R. (2003). Case study research: design and methods. 3rd ed. Thou-sand Oaks, CA: Sage Publications 


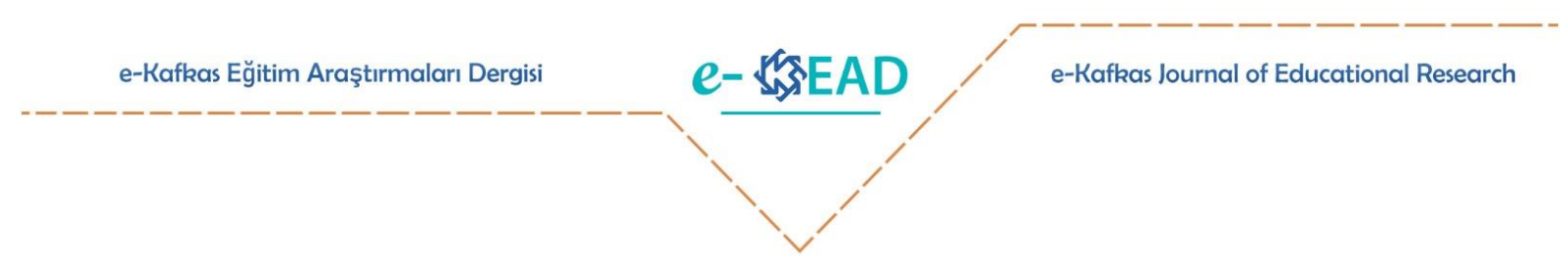

\section{Investigation of Pre-service Teachers' Knowledge Integration Levels on pH Balance of the Body}

\section{Fatma Şahin Filiz Kabapınar}

To cite this article: Şahin, F. ve Kabapınar, F. (2020). Öğretmen adaylarının vücudun pH dengesi konusunda bilgi entegrasyon düzeylerinin incelenmesi. $e$ - Kafkas Eğitim Araştırmalarl Dergisi, 7, 1-15. doi:10.30900/kafkasegt.664823

\section{Research Article}

Received: 25.12 .2019

\section{Introduction}

Researchers emphasize in recent years that local and global problems cannot be solved with the help of knowledge from a single discipline. Therefore it is frequently underlined that defining and solving such complex problems require interdisciplinary knowledge. It is stated that some problems related to energy, environment, health and ecology are of vital importance and cannot be solved with knowledge of a single discipline alone (Newell, 2007). According to Rhoten \& Parker (2004) university students need to practice interdisciplinary thinking during their formal education in order to be prepared for the twenty-first century. However, the basic applications of science education are still disciplinary in nature. In primary and secondary schools, students take courses that appear to be integrated under the name of science. Upon the aforementioned course content is examined, it is seen that the units and learning areas are again separated on the basis of unique discipline. At the high school level, the courses are completely different from each other and are taught by teachers who are experts in that discipline. This situation restricts students and teachers' awareness of the necessity of interdisciplinary knowledge for concept and skill acquisition, while reducing the probability of students and teachers having an interdisciplinary knowledge and understanding. During their schooling students attend various courses represent different individual disciplines. They however remain unguided about how to integrate these knowledge pieces coming from different disciplines. Therefore educators emphasize the necessity of designing instructional programmes based on interdisciplinary view of learning by leaving disciplinary view of learning behind (Shen \& Linn, 2011). Such instructional programmes require interdisciplinary transfer that refers to the processes in which students successfully apply descriptive models, concepts, methods and skills that they learnt in a certain discipline to another so as to understand events or solve problems. This phenomenon is defined as in-depth transfer in the related literature (Mansilla, 2005). Researchers highlight interdisciplinary collaboration as a means for in-depth transfer and the concept of "integration of knowledge" to express the need for a common understanding among researchers (Newell, 2007; Akera, 2007; Dewulf et al., 2007). There are three specific processes in the integration of interdisciplinary knowledge. These are translation, transfer and transformation (Shen et al., 2014). Thus all these explanation levels of interdisciplinary are expected to be covered during the instructional programmes at any level of schooling.

\section{The purpose of the study}

As many fields of education teachers have a great role in helping students to be prepared for solving complex problems. However, teachers need to be prepared for themselves for such endeavour in the first place. If the teachers have interdisciplinary thinking skills, their students might also be successful in establishing interdisciplinary relationships. The question whether this is the case motivated the present study. In other words it aims to investigate prospective chemistry teachers' interdisciplinary knowledge about $\mathrm{pH}$. The research question of the study can be stated as "Can the prospective chemistry 
teachers use knowledge regarding $\mathrm{pH}$ that they acquired during their chemistry courses to solve interdisciplinary complex problems?" The research question of the study is "Can prospective chemistry teachers use knowledge regarding $\mathrm{pH}$ that they gained during their chemistry courses to solve interdisciplinary complex problems?

\section{Methodology of the study}

Case study approach was adopted in the study. Case study is one of several ways to do social and scientific research. According to Yin (2003), four types of case study patterns can be mentioned: the holistic single state pattern, the nested single state pattern, the holistic multi state pattern and the nested multi state pattern. In this study, it was aimed to determine prospective chemistry teacher' interdisciplinary knowledge concerning $\mathrm{pH}$ balance of the body. Within this framework, there is only one case that is the subject of the study and it guided this research with its "Holistic Single Case Pattern" assumptions and application principles. As can be understood from its name, in this pattern, a single analysis unit (prospective chemistry teachers) will be considered as a holistic and single unit.

\section{Participants}

Participants of the study were 14 university students who attend the 4th year of chemistry education at a state university located in İstanbul.

\section{Data Collection Tool}

An open-ended concept test was designed and used as data collection tool in order to determine participants' interdisciplinary explanations about $\mathrm{pH}$ balance of the body. The $\mathrm{pH}$ Concept Test consists of 19 open-ended questions. Special attention was paid to design interdisciplinary questions. The concept test was distributed to participants without under the time constraints in 2018-2019 academic year. Questions' requirement concerning interdisciplinary knowledge was differ in nature as some of the questions appeared on the test could be answered via the knowledge of a single discipline. On the other hand, some questions required the interdisciplinary knowledge involving two-three disciplines or involving multi-discipline (more than three disciplines together).

\section{Data Analysis}

Content analysis was used in sorting out and analysing the written responses of prospective chemistry teachers. The reliability of content analysis and thereby the reliability of the study was achieved by intercoder reliability. Thus prospective chemistry teachers' written responses were coded by two researchers independently. Participants' knowledge integrations were analysed as translation (forming a common language when defining a scientific concept in different disciplines), transfer (enabling indepth, interdisciplinary reasoning of previously acquired knowledge in case of new problems encountered) and translation (an interdisciplinary transformation by applying concepts learned from a discipline) realization potential). Relationship levels, related disciplines, related content and sample explanations were analysed at each level.

\section{Findings}

The present study targeted to investigate prospective chemistry teachers' use knowledge regarding $\mathrm{pH}$ that they gained during their chemistry courses to solve interdisciplinary complex problems. To do so they were asked to solve a number of problems with differential complexity. In solving or attempting to solve these problems prospective chemistry teachers need to use knowledge coming from their main discipline, that is chemistry, and need to provide explanations concerning the issue at hand. During their problem solving process it would be possible to uncover and examine prospective chemistry teachers' interdisciplinary levels of knowledge integration. Findings of the study indicated that prospective chemistry teachers were successful in explaining the concepts of acid base (94\%), buffer systems (84\%), acid base balance (59\%) and $\mathrm{pH}$ level of blood (50\%). They also reveals that three prospective chemistry teachers provided explanations at the level of translation and other four gave responses at the transfer level regarding the $\mathrm{pH}$ balance of the human body. None of the participants 
appeared to be at the level of transformation that required using the $\mathrm{pH}$ knowledge they acquired during their chemistry courses.

\section{Conclusion and Recommendations}

As future teachers prospective chemistry teachers will be expected to render their students to solve problems of any kind such as daily, local, social and global. These problems require different knowledge systems and different disciplinary explanations. Therefore it will not be adequate to donate prospective chemistry teachers to chemistry knowledge or knowledge related to biology or physics. Rather they need to be ready to integrate knowledge coming separately from different disciplines. According to the results of the presents study prospective chemistry teachers were failed to do so. They were successfully in explaining chemistry concepts. However, they failed to explain the concepts requiring multi-disciplinary knowledge such as the importance of $\mathrm{pH}$ for public health, exercise and $\mathrm{pH}$, the balance of the nervous system by regulating the balance of our body. Majority of prospective chemistry teachers used single discipline in their explanations regarding problems. Only a quarter of prospective chemistry teachers used multidisciplinary explanations. 